\title{
Factors Influencing Household Adoption of Solar Home System in Baso Liben District, Amhara Regional State of Ethiopia
}

\section{Asmare Mossie Zeru ( $\sim$ asmare410@gmail.com )}

Federal technical and vocational education and training agency https://orcid.org/0000-0002-08837097

\section{Dawit Diriba Guta}

Center for environment and development studies, college of development studies, Addis Ababa university

\section{Original article}

Keywords: Solar home system, Adoption, Factors, Household, Rural

Posted Date: February 9th, 2021

DOI: https://doi.org/10.21203/rs.3.rs-60920/v2

License: (c) (i) This work is licensed under a Creative Commons Attribution 4.0 International License. Read Full License 
Factors Influencing Household Adoption of Solar Home System in Baso Liben District, Amhara Regional State of Ethiopia

\author{
Asmare Mossie Zeru ${ }^{a}$, Dawit Diriba Guta ${ }^{b}$ \\ ${ }^{a}$ Federal Technical and Vocational Education and Training Agency, email: \\ asmare410@gmail.com \\ ${ }^{\mathrm{b}}$ Center for Environment and Development Studies, College of Development Studies, Addis \\ Ababa University, e-mail: davdiriba@yahoo.com \\ Corresponding author's email: davdiriba@yahoo.com
}




\begin{abstract}
Background: Although solar energy is abundant, accessible, affordable, and ecologically and environmentally friendly, in rural Ethiopia the majority of households are still using pollutant kerosene for lighting. It is important to understand the demand and supply-side factors affecting adoption of technology. For this purpose, this study investigates the factors influencing household adoption of the solar home system (SHS).
\end{abstract}

Methodology: The data used for the econometric model was collected from randomly selected 228 solar home system adopter and 143 non- adopter households in Baso Liben district, Amhara regional state of Ethiopia. The logistic regression model was applied to examine the factors affecting households' willingness to adopt SHS.

Results: The finding of this study shows significant variation in many of the socioeconomic and demographic characteristics between adopters and non-adopters. The result of the binary logistic regression model indicated that as income of a household increase, their propensity to adopt solar home system also increases. Likewise, participation in off-farm income activities, house type, educational status of the head, training access, media access, and prior knowledge of the technology positively correlated with the probability of adoption. On the other hand, the gender of the head (being male) and access to electricity were negatively associated with the adoption of SHS.

Conclusion: Therefore, policy measures should create awareness through training, education, and information access or better media availability, and improving the economic status of households through creating lucrative off-farm income-earning opportunities to achieve enhanced adoption of the solar home system.

Keywords: Solar home system, Adoption, Factors, Household, Rural 


\section{Introduction}

Energy access to the human being is a precondition requirement for development and welfare as well as successful economic development and job opportunity [1]. Solar energy is among the cleanest, accessed with low prices and abundant sources of energy with a minimum ecological and environmental hazard. The share of renewable energy in the global electricity generation reached $28 \%$ in the first quarter of 2020 of which, among renewables, the share of solar reached 2\% [2]. According to IEA [3], in sub-Saharan Africa, about 55\% of the population(600 million people) does not have electricity access. But the continent has a huge and abundant source of renewable energy. For instance, the capacity of the continent's annual solar radiation ranging from 5 to $7 \mathrm{kWh} / \mathrm{m} 2[4]$.

Regarding Ethiopia, the need for electricity is still huge. As the evidence showed, more than half of the total population of the country $(56 \%)$, more than that of the average of Sub-Saharan Africa (55\%), still doesn't have access to electricity [5]. To increase access to electricity the government has been implementing two strategies, namely extension of the national grid and the provision of off-grid modern energy technologies [6]. The average daily solar radiation of Ethiopia reaching the ground as a whole is $5.26 \mathrm{kWh} / \mathrm{m}^{2}$. This varies significantly during the year, ranging from a minimum of $4.55 \mathrm{kWh} / \mathrm{m} 2$ in July to a maximum of $5.55 \mathrm{a} \mathrm{kWh} / \mathrm{m} 2$ in February and March. On a regional basis, the yearly average ranges from $4.25 \mathrm{kWh} / \mathrm{m} 2 /$ day in the extreme western lowlands to $6.25 \mathrm{kWh} / \mathrm{m} 2 /$ day in the Adigrat area [7], and has a total solar energy reserve potential of 2.199 million TWh per annum [8].

In addition to the low accessibility of electricity, the sector is primarily that dependent on hydropower. This increases its vulnerability due to the increased risk of drought caused by climate change [9]. As stated by Lighting Africa [10], there is also a great disparity of power distribution in the country. In Ethiopia, as in most of the SubSaharan Africa countries, the gap between urban and the rural sector in terms of access to electricity is huge. About $96 \%$ of urban households of the country are connected to the grid (99.9 \% in Addis Ababa), whereas only $27 \%$ of households living in rural areas of the country have access to electricity services [10]. Furthermore, lack of electricity is particularly experienced in rural areas, where 5\% of the people have access to electricity. As noted by TERI [11], such a problem is 
mainly emanated due to the difficulty and expensiveness of connecting the rural population living in isolated villages to a centralized electric grid. Due to this reason, most of the households in rural villages depend on Kerosene lamps for lighting and wood and charcoal for cooking, which causes adverse effects on the environment as it emits a lot of carbon and also damages the health of the people using it [12].

Many studies have assessed the determinants of solar home system adoption in different countries. For instance, some of the studies such as Keriri [13], Gitone [14] and Regina [15] in Kenya; Tahir [16] in Pakistan; Guta [17]; Anteneh [18]; and Legesse [19] in Ethiopia studied the socio-economic and demographic factors affecting household adoption of the solar home system. These studies have applied different models to estimate factors determing household adoption of solar home system. Anteneh [18] and Legesse [19] revealed the effects of the level of education of the household, land size, number of cattle, level of income, and age of the head of household on solar home system adoption. Whereas in addition to those variables, Guta [17] investigated the effects of many more variables in a broad sense such as trees on private property, and saving. Besides, other determinants such as institutional factors including access to credit and cooperative membership [17, 18], level of knowledge and awareness [18] and household use of alternative source of energy [19] have been investigated. However, there is a research gap in these empirical studies in addressing institutional factors such as awareness creation training given to the households either formally or informally. Besides, housing types could affect households' willingness to adopt solar home systems were not addressed properly. Moreover, there is also little information about how household access to communication technologies could affect the adoption decision.

Therefore, this paper mainly focused on filling the observed gap by examining the factors that influence household adoption of the solar home system by controlling these key factors overlooked by previous studies. The result of the study will have development and policy significance by providing current and valuable evidence, which can be used by policymakers to make an informed decision in the formulation of effective development programs, and strategies for addressing the rural energy crisis. 


\section{Literature Review}

\subsection{Theoretical views}

In this section, three theoretical views that have relevance with the idea of adopting the solar home system will be discussed. The first one is the theory of reasoned action, which is developed by Fishbein and Ajzen in 1975. The theory proposed that rational thought grounds human behaviour, and the model uses the principle of compatibility, which predicts that attitudes reflect behavior [20]. As explained by Ajzen and Fishbein [21], if people evaluated the suggested behavior as a positive attitude and if they think others want them to perform the behavior or subjective norm, this results in a higher intention (motivation) and they are more likely to perform the behavior. Subjective norms and beliefs shape these attitudes, and situational factors affect these variables' relative importance. According to this theory, attitude and subjective norm are important determinants of the intentions of peoples to act such as adopting and using new technology such as the solar home system.

The second theory is innovation diffusion, was first developed by Rogers [22]. The theory proposed that technology adoption behavior of an individual such as a solar home system is determined by his or her perceptions regarding relative advantage, compatibility, complexity and observability of an innovation which influence the rate of innovation adoption. According to Rogers [22], adoption decision towards new technologies encompasses five stages; including knowledge, persuasion, decision, implementation and confirmation, in a sequential manner. An individual at the knowledge stage becomes aware of innovation. At the persuasion stage, an individual develops a favorable or unfavorable attitude towards innovation. At the decision stage, the individual engages himself/herself in activities that lead him/her either to adopt or reject the technology. At the implementation stage, the individual intends to use the technology and finally, confirms the adoption decision towards the innovation. These communication channels or interpersonal exchange of information is more powerful in convincing a social system to accept new technologies. Based on these facts, this paper addressed some related factors including the level of knowledge and awareness that could influence households' decision towards adopting SHS. 
On the other hand, the energy ladder and fuel stacking hypothesis show the relationship between an increase in the economic well-being of the household and the type of fuel they tend to use. According to Hosier \& Dowd [23], as income raises households to consume fuels that occupy higher rungs, ascending the energy ladder. By considering this fact, the paper examined how the economic status or income level of households, affect their decision to adopt modern energy technologies, in this case, SHS. Fuel stacking also explains the case where households simultaneously use multiple fuels usually on both upper and lower stages on the energy ladder [24]. Based on energy stacking, this paper also examines how socio-economic and demographic variables affect households decision towards adopting SHS.

\subsection{Literature from empirical research works}

In developing countries, lack of access to clean energy is associated with infirmity and the prevalence of poverty $[25,26]$. On the other side, adoption of renewable energy is derived by several factors including cost competitiveness, growing environmental concern, better access to financing, dedicated policy initiatives, energy security, growing demand for energy in developing and economic growth as well as an increasing need of access to modern energy technologies [27, 28, 26]. Moreover, with technological advancement, the cost of installation of solar photovoltaic systems that use solar panels has declined rapidly. Thus, the adoption of solar energy has increased in the last few decades [26]. In addition, lack of regular power supplies also motivated household adopters to buy and install solar photovoltaic cells and sustainability was a driver to promote adoption among various organisations [29, 26]. In order to understand the context-specific challenges hindering SHS market, further researche is required, which in turn increases the knowledge to scale up solar energy solutions [30]. In Sub Saharan Afriica, most of the population is dependent on traditional fuel and only a small proportion of the households have access to the electric grid [26]. Since every country is different and the challenges they faced are not the same, all measures might not be the same for each of them [31].

The level of awareness and knowledge highly determines the household adoption of the solar home system $[32,19,33]$. Hence, an adequate level of awareness and correct information should be provided to bring a better understanding of both benefits and disadvantages of renewable technology [34]. Lack of adequate information of 
households on the negative health outcomes associated with the inefficient combustion of solid fuels impedes the growth of market demand for clean energy [35].

Households' use of technology varies according to their way of life and living environment. Accordingly, in rural areas, households adopt SHS where the grid can not be readily accessed or not available. But in urban areas households employ SHS as an alternative to grid unreliability or a replacement for high-cost diesel/gasoline backup generators. Furthermore, based on their degree, households or small business may start with Pico and eventually move up to SHS [36].

A study conducted in Ethiopia revealed institutional barriers, for instance, lack of coordination among the health and energy sectors, ministerial departments, regional and national agencies, the public and the private sector, and national and international agencies [35]. Coordination among ministries to ensure a better understanding of clean energy to make it a priority is weak. The child and maternal health units of the Ministry of Health do not promote awareness of the health risks of household air pollution. As stated by Beyene [35], key institutions have overlapping mandates and insufficient technical staff and instrumentation to provide diversified energy sources at different levels.

A study found that an increase in accessibility of credit enhances household adoption of new technologies [37]. Training delivered to households affects the adoption of the SHS. A study conducted in Kenya found that there is a positive relationship between the individuals who had received informal or formal training on solar systems and use [13]. To be more confident about the innovations, training can help people towards the adoption and active usage of the technologies provided [38], adds crucial value in the minds of trainees where they acquire this by performing practically the knowledge or the information they read and heard from different sources [39].

Many researchers investigated the effects of demographic and socioeconomic factors affecting households' willingness to adopt the solar home system. Anteneh [18] examined the determinants of household adoption of the solar home system. The author showed that income, numbers of cattle, off-farm activity, marriage, and education level have a positive effect on willingness to pay for the solar home system, but age and family size has a negative effect. He also revealed that female-headed 
households are less likely to adopt the solar home system compare to male-headed households and it is statistically significant.

Guta [17] investigated the determinants of household adoption of the solar home system. The finding showed that the income of the household, landholding size, number of cattle, age of household head, family size, and education level of the head has a positive effect on solar home system adoption. The author also found that maleheaded households are less likely to adopt a solar home system compared to femaleheaded counterparts. This corresponds with Patrick [40], who found that femaleheaded households are more likely to adopt solar home system compared to male counterparts. Similarly, Legesse [19] revealed that household income and the number of cattle have a positive effect on solar home system adoption. On the contrary, the age of the household head, location of households from agricultural extension centre, market, main road, and electric grid have a negative effect on the adoption of renewable energy sources.

Abera [6] examined determinants of lighting Energy transitions in rural Ethiopia, who revealed that landholding size, level of education, house type, and modern communication technologies have a positive influence on the adoption of renewable energy resources including solar. But family size has a negative effect on solar home system adoption.

De Groote et al [41] investigated the heterogeneity in the adoption of the photovoltaic system in the region of Flanders (Belgium). The author explained that important housing characteristics such as house size, roof insulation, and quality of the roof are positively correlated with the solar photovoltaic installation. He also showed that as the age of the house increase, the rate of adopting the solar home system decrease.

In the review of the above literature, numerous factors determining household adoption of solar energy are investigated. However, there is little information about the effect of determinants including, training, house type, and communication access on household adoption of SHS, particularly in rural Ethiopia. 


\section{Methodology}

\subsection{The study area}

The study was conducted in Baso Liben district, East Gojjam zone of Amhara region, northern Ethiopia. It has GPS coordinate of $10^{0} 09^{\prime} 60.00^{\prime \prime} \mathrm{N}$ latitude and $37^{0} 34^{\prime} 59.99^{\prime \prime}$ E longitude. It is located $307 \mathrm{~km}$ northwest of Addis Ababa, the capital city of Ethiopia, $292 \mathrm{~km}$ from regional city Bahir Dar and $27 \mathrm{~km}$ from Debre Markos (Zone capital town). The total area of the district is about 113,284 hectares with two agroecological zones of woyina dega (46\%) and kola (54\%). The district has 22 rural and 4 urban and semi-urban kebeles (The lowest administrative unit in Ethiopia, which is made up of several villages). The total population of the district is 170,387 , of which the number of men and women accounts $47.4 \%$ and $52.6 \%$ respectively. Out of the total population of the district, only $7.9 \%$ of the population is urban residents and the majority $(92.1 \%)$ are rural residents. Figure 1 below shows the map of the study area.

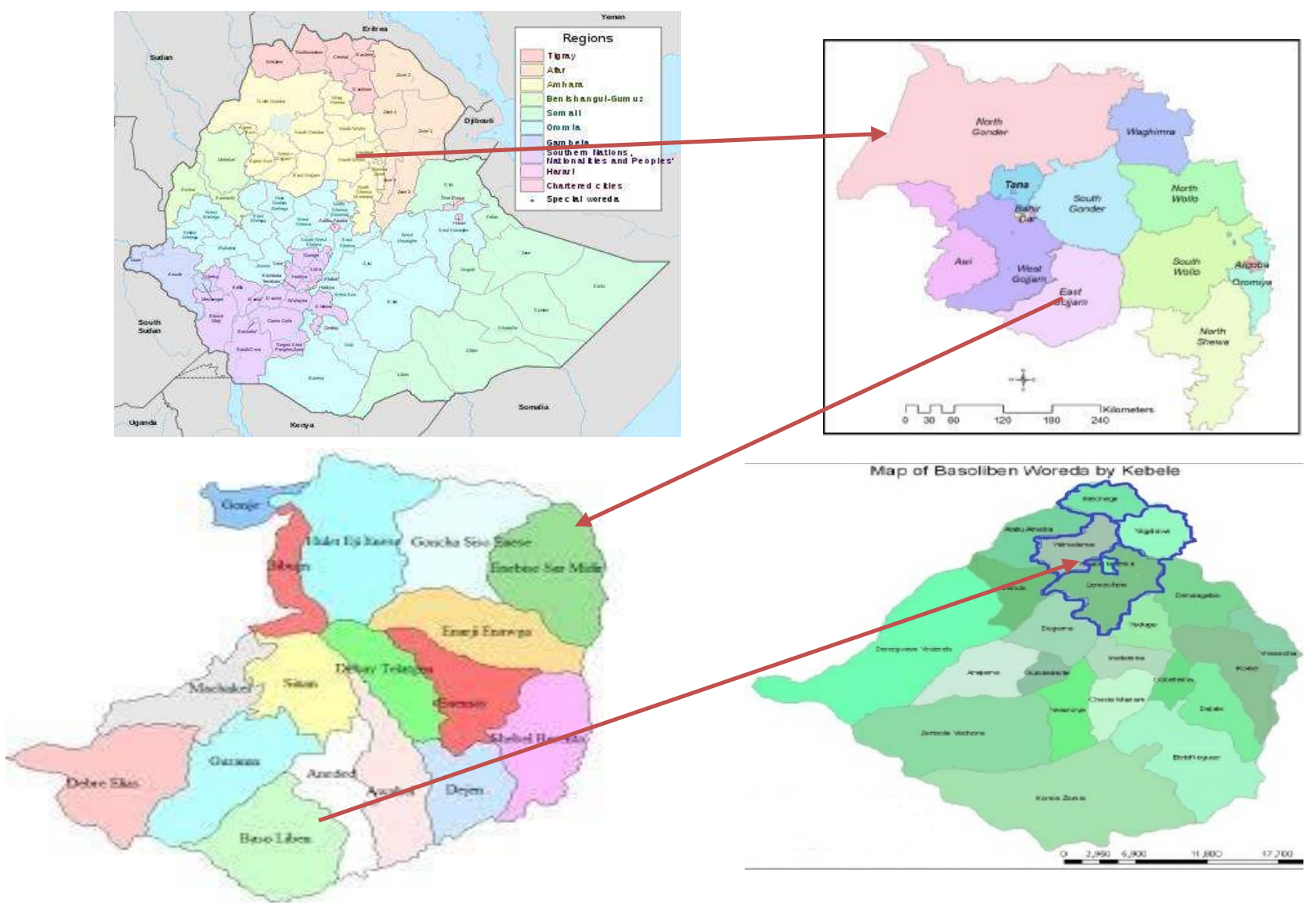

Figure 1: Map of the study area 


\subsection{Sampling techniques, the data and analysis of the study}

To collect the data used for this paper, a cross-sectional research design was employed. Among 22 rural kebeles of the District, 4 of them namely; Yelemelem Limichim, Yegelaw \& Michig were purposively selected based on infrastructural accessibility, time, and other biophysical factors such as difficult topography. Sample households were randomly selected from both adopted and non-adopted households living in selected kebeles using proportionate sampling approach. According to the 2019 survey report of the woreda, the total households of the selected kebeles were 5170 of which 3195 were solar adopter (766 from Yelemelem, 747 from Yegelaw, 512 from Michig and 1170 from Limmichim kebeles) and 1976 were non-adopters (571 from Yelemelem, 71 from Yegelaw, 513 from Michig and 821 from Limichim kebeles) (Baso Liben woreda survey report, 2019).

A total sample of 371 households participated in the study. Of which 228 households were SHS adopted households (55 from Yelemelem, 52 from Yegelaw, 37 from Michig and 84 from Limichim) and 143 were non-adopted households (41 from Yelemelem, 6 from Yegelaw, 37 from Michig and 59 from Limichim kebeles). The data collection was undertaken from 02 February to 06 March 2020 using structured and semi-structured questionnaires. During data collection, four enumerators were closely supervised by the researchers to ensure data accuracy and completeness. The survey questionnaires comprised the demographic characteristic, socioeconomic variables and other pertinent variables. During the time of conducting this research, a pilot study was carried out to test the reliability of data collection tools by using $10 \%$ of the respondents. Hence, Cronbach's alpha was applied to calculate the reliability of data gathering tools and found to be 0.714 . According to George and Malley [42], the result of reliability from cronbach's alpha coefficient ranges from 0.7 to 0.79 is considered as acceptable. Therefore, since the reliability test for data gathering tools of this research is 0.714 , the overall internal consistency was acceptable. While the qualitative data were analyzed using content analysis, the quantitative data were also analyzed using both descriptive and inferential statistics with the help of SPSS version 23. 


\subsection{Empirical models of solar home system adoption}

The study used a binary logistic regression model since the dependent variables are dichotomous. This means that it takes the value of 1 if someone adopts a solar home system and it has a value of 0 if not [43]. The reason behind using this model in the study than the probit model is that the equations of the logit model are and it is directly interpretable as log-odds [44]. This model is also used in previous studies by several researchers for the same issue, for instance, Guta [17] and Akinwale and Adepoju [45]. According to Park [46], there are two models of logistic regression, binary logistic regression, and logistic regression models. Binary logistic regression is used when the dependent variable is dichotomous (only two categories) and the independent variables are either continuous or categorical [45].

The logit regression uses the maximum likelihood method to estimate parameters in the model after transforming the response variable into logit [47]. The product of the probabilities of solar energy adoption success and non-adoption specifies the maximum likelihood of the models. The coefficients of the logit model, like the ordinary regression coefficient, define the parameter estimates. According to Gujarati [43], the equation of the model is written as follows after converting the dependent variable into the natural log of the odds (logit):

$P_{i}=E\left(Y=1 / X_{i}\right)=\frac{1}{1+e^{-\left(B_{1}+B_{2} X_{i}\right)}}$

Where $\left(\mathrm{p}_{\mathrm{i}}\right)$ is the probability of adopting SHS, $\left(\mathrm{x}_{\mathrm{i}}\right)$ stand for the set of explanatory variables (i.e. income, off-farm income, educational status of head, the gender of the household head, age of the household head, marital status, land size, number of cattle, family size, housing type, prior knowledge or awareness, distance to main road, distance to market, distance to farm extension, credit accessibility, training access, mobile access, media access, and electricity access).

When equation 1 is the logistic regression equation, let consider, $Z_{i}=B_{1}+B_{2} x_{i}$ or replaced by $z_{i}$ in the first equation, then we obtained equation 2 .

$P_{i}=\frac{1}{1+\mathrm{e}^{-\mathrm{z}_{\mathrm{i}}}}=\frac{\mathrm{e}^{\mathrm{z}}}{1+\mathrm{e}^{\mathrm{z}}}$

In equation $2, Z_{i}$ exist between $-\infty$ and $+\infty$ and $P_{i}$ is between 0 and 1 . Where $P_{i}$ shows the probability of households who use the solar home system, and $X_{i}$ is the explanatory variable, (i) is an individual household observation (where pi equal to 1 
the probability that households use the solar home system and 1- $P_{i}$, is the probability of households that can be categorized under not using. Then, the probability of households who do not use can be explained in equation 3 as follows:

$1-P_{i}=\frac{1}{1+e^{z_{i}}}$

Equation 4 can be obtained by dividing the households who use it to those who do not use the solar home system. Therefore, the equation is;

$\frac{p_{i}}{1-p_{i}}=\frac{e^{z_{i}}\left(1+e^{\left.z_{i}\right)}\right.}{1+e^{z_{i}}}=e^{z_{i}}$

Using the natural logarithm of both sides of the equation, equation (5) can be obtained

$$
\ln \left(\frac{p_{i}}{1-p_{i}}\right)=\ln \left[e^{B_{O}}+\sum_{i=1}^{M} B_{i} X_{i}\right]=Z_{i}
$$

When the disturbance term Ui is taken into account, the logit model becomes:

$$
Z_{i}=B_{o}+B_{1} X_{1}+B_{2} X_{2}+B_{3} X_{3}+\cdots \cdot B_{m} X_{m}+u_{i}
$$

Where $\mathrm{Bo}$ is the intercept, $B_{1}, B_{2}, B_{3} \ldots$ are the coefficients to be estimated in the model. The slope coefficient indicates the change log-odds in favor of being adopting the solar home system as an independent variable change. $X_{i}$ stands for the vector relevant characteristics of households identified below, and $U_{i}$ is an error term.

$Z_{i}=B_{o}+\sum_{i=1}^{M} B_{i} X_{i}+U_{i}$

\subsection{Identification of explanatory variables}

Household income is one of the socioeconomic factors that could affect the adoption of a solar home system. Many scholars indicated that as households' income gets higher, their propensity to adopt the solar home system also increases [17- 19]. Moreover, asset variables (number of cattle and landholding size) positively affect solar energy. Therefore, the number of cattle and landholding size is expected to positively influence households' willingness to adopt SHS [17-19]. Participating in off-farm income-earning activity is one of the key socioeconomic factors that could affect solar home system adoption. Off-farm income is considered as a substitute for borrowed capitals for rural household economies where credit availability is either misplaced or dysfunctional [48]. Households who have additional income (remittance) were more likely to invest in the solar home system [48]. Therefore, this is also expected to have a positive effect on SHS adoption.

Empirical studies concerning demographic variables are inconclusive and still debatable. Regarding gender of household head, there are two contrasting groups, 
which means the first group argued that male-headed households are more likely to adopt the solar home system, for instance [18]. Conversely, the other literatures argued that female-headed households are more likely to adopt solar home system $[17,46]$. Some literatures revealed that older household heads are less likely to adopt solar home system compared to younger ones $[18,19]$. That means as households' head get older, their willingness to adopt solar home system decrease. But other studies found that households' age has a positive influence on solar home system adoption because it might be related to the fact that older household heads may be wealthier as they accumulate more productive resources that enable them to invest in the solar home system [17]. In this study age of households' head is hypothesized to affect SHS adoption either positively or negatively. Likewise, family size is expected to have either a positive or negative influence on SHS adoption. Studies indicated that family size has a negative effect on solar home system adoption $[14,18,6]$. This is because households with large family sizes spend more resources in upholding their children rather than investing in a solar home system. The other study also revealed that household size has a positive effect on solar home system adoption [17]. But marital status is expected to have a positive influence on SHS adoption. A study stated that married household heads are more likely to adopt a solar home system than either single or divorced household heads [18].

Regarding education, studies revealed that the education level of household heads has a positive effect on solar home system adoption [6,17 and 18]. This is because of the reason that education enhances individuals' health and environmental awareness that helps them to choose clean and modern energy sources. Thus, in this study, the educational status of household heads is expected to positively influence the adoption of SHS [41, 17 and 6]. Similarly, the type and size of the house are expected to positively affect SHS adoption. Some studies found that the number of rooms of houses has a positive correlation with solar home system adoption [41, 6]. Prior information or knowledge that households have about the solar home system is considered as one driving factor of solar energy adoption [32]. Therefore, it is proposed to influence SHS adoption positively in the model estimation.

Training is one of the institutional factors considered as a key driving factor of solar home system adoption at the household level. Training given to households about the 
solar home system has a positive effect on their decision to adopt [13]. The other study also added that training can help people to be more confident about the innovations for adoption and active usage of the technologies provided [38]. Therefore, in the study, training is controlled in the model and it is hypothesized to positively affect SHS adoption. Likewise, credit accessibility is the other institutional factor to be estimated in the model. One literature stated that an increase in accessibility of credit enhances household adoption of new technologies [37]. This is because it can assist rural households to purchase technological products they needed. Therefore, access to credit was expected to positively affect SHS adoption.

Adoption of the solar home system could be influenced by media (either radio or TV) and mobile phone access. Media and phone access create exposure to households to be more aware of new and timely information about new technologies. Regarding this, a previous study revealed that the accessibility of modern communication technologies including radio and mobile cell phones found to have a positive influence on the adoption of modern and clean energy technologies [6]. Thus, in this study, both media and cell phone access are expected to have a positive effect on the adoption of SHS.

Distance from home to different infrastructures including the main road, market, and agricultural extension centre is also considered as key factors expected to affect solar PV technology adoption. Legesse [19], found that both distances from home to the main road and agricultural centre have a negative effect on households' willingness to adopt the solar home system. This is due to the reason that the average distance of households to agricultural extension centres might affect their information accessibility regarding solar and other agricultural extension services that would influence their product. Likewise, the distance from home to the surrounding market negatively affects solar home system adoption [19]. That means since solar products are found in market areas, households close to the market are more adopters. Therefore, distance from home too, main road, agricultural extension centre, and market are proposed to negatively influence SHS adoption. Similarly, households' access to electricity is expected to negatively affect SHS adoption. A study revealed that poor access to electricity in developing countries facilitates solar energy adoption 
[16]. Table 1 shows a detailed description of the variables used in the model and the hypothesized effect on SHS adoption.

Table 1. Description of Explanatory Variables and their expected effect on the household adoption of solar home system

\begin{tabular}{|c|c|c|c|}
\hline Variables & Description & $\begin{array}{l}\text { Expected } \\
\text { sign }\end{array}$ & Sources \\
\hline $\log$ income & Continuous variable, Birr & + & $\begin{array}{l}\text { Guta, 2018; } \\
\text { Anteneh, 2019; Legesse, } \\
2016\end{array}$ \\
\hline land & Continuous variable, number & + & $\begin{array}{l}\text { Abera, 2019; Legesse, } \\
2016(+), \text { Guta, } 2018\end{array}$ \\
\hline Cattle(TLU) & Continuous variable, number & + & $\begin{array}{l}\text { Anteneh, 2019; Legesse, } \\
2016\end{array}$ \\
\hline $\begin{array}{l}\text { Off-farm } \\
\text { income }\end{array}$ & $\begin{array}{l}\text { Dummy, } 1=\text { If the household } \\
\text { has off-farm income, } 0= \\
\text { otherwise }\end{array}$ & + & $\begin{array}{l}\text { Obayelu A., } 2017 \\
\text { Anteneh, } 2019\end{array}$ \\
\hline Gender & Dummy, $1=$ male, $0=$ female & \pm & $\begin{array}{l}\text { Guta, 2018; Anteneh, } \\
2019 \\
\text { Patrick, 2009) }\end{array}$ \\
\hline Age & Continuous variable, year & \pm & $\begin{array}{l}\text { Guta, 2018; Anteneh, } \\
\text { 2019; Legesse, } 2016\end{array}$ \\
\hline Family size & Continuous variable, number & \pm & $\begin{array}{l}\text { Gitone, 2014, Anteneh, } \\
\text { 2019; Guta 2018, Abera, } \\
2019\end{array}$ \\
\hline Marriage & $\begin{array}{l}\text { Dummy, } 1=\quad \text { single, } \\
\text { married, } 3= \\
\text { widowed }\end{array}$ & + & Anteneh, 2019 \\
\hline Education & $\begin{array}{l}\text { Dummy, } 1=\text { Literate, } \quad 0= \\
\text { Otherwise }\end{array}$ & + & $\begin{array}{l}\text { Abera, } 2019 \text {; Guta, } \\
\text { 2018; Anteneh, 2019; }\end{array}$ \\
\hline House type & $\begin{array}{l}\text { Dummy, } 0=\text { one-room tin- } \\
\text { roofed house, } 1=\text { two-room } \\
\text { tin-roofed house, } 2=\text { three and } \\
\text { above room tin-roofed house }\end{array}$ & + & $\begin{array}{l}\text { De Groote et al. 2016, } \\
\text { Abera, } 2019\end{array}$ \\
\hline Prior info. & $\begin{array}{l}\text { Dummy, } 1=\text { if the household } \\
\text { has prior } \\
\text { information/knowledge about } \\
\text { solar energy, } 0=\text { otherwise }\end{array}$ & + & Naomi, 2014 \\
\hline Training & $\begin{array}{l}\text { Dummy, } 1=\text { If household got } \\
\text { training, } 0=\text { otherwise }\end{array}$ & + & $\begin{array}{l}\text { Keriri ,2013; } \text { Bizien, } \\
\text { 2017; Ali, } 1998\end{array}$ \\
\hline Credit & $\begin{array}{l}\text { Dummy, } 1=\text { If household got } \\
\text { access to credit, } 0=\text { otherwise }\end{array}$ & + & Khushbu et al, 2015 \\
\hline phone & $\begin{array}{l}\text { Dummy, } 1=\text { if household has } \\
\text { a cell phone, } 0 \text { if not }\end{array}$ & + & Abera, 2019 \\
\hline Media & $\begin{array}{l}\text { Dummy, } 1=\quad \text { Yes, } \quad 0= \\
\text { otherwise, }\end{array}$ & + & Abera, 2019 \\
\hline
\end{tabular}




\begin{tabular}{llll}
\hline Distmarket & Continuous, kilo meter & - & $\begin{array}{l}\text { Legesse, 2016; Anteneh, } \\
\text { 2019; Keriri, 2013 }\end{array}$ \\
Distagriext. & Continuous, kilo meter & - & Legesse, 2016 \\
Distroad & Continuous, kilo meter & - & Legesse, 2016 \\
$\begin{array}{l}\text { Electricity } \\
\text { access }\end{array}$ & $\begin{array}{l}\text { Dummy, 1= if household got } \\
\text { access to electricity, 0= } \\
\text { otherwise }\end{array}$ & \\
$\begin{array}{l}\text { Kebele- } \\
\text { Kummy }\end{array}$ & $\begin{array}{l}\text { Kebele dummy (0= Michig, } \\
\text { 3= Yelemelem, 2= Limichim, }\end{array}$ \\
\hline
\end{tabular}

\section{Result and Discussion}

\subsection{Descriptive analysis}

Table 2 below summarizes the result from descriptive statistics of adopters and nonadopter households of SHS. As shown in the table, a total of 371 (61.5\% adopted and $38.5 \%$ non-adopted) household respondents participated in the study. Of which $90.8 \%$ were males and 9.2\% were females headed households. From adopted households, $92.5 \%$ of them were male-headed and $7.5 \%$ were female-headed, whereas the male and female-headed non-adopted households were $88.1 \%$ and $11.9 \%$ respectively. The chi-square test indicated that there is no statistical association between the sex of respondents and the decision to adopt SHS. The mean ages of adopted and nonadopted respondents of the SHS were 48.06 and 52.29 years respectively. This indicates that the non-adopter households of SHS were relatively older than adapters. The $\mathrm{P}$-value of the $\mathrm{t}$-test for this result indicated that there is a significant $(\mathrm{P}<0.01)$ mean difference between the age of SHS adopters and non-adopters. On the contrary, Guta [17] revealed that household heads of SHS adopters are relatively older than non-adopters.

The average family size of households was 4.91 , which is a bit more than the national average rural family size of the country, which was 4.9 [49]. The average family sizes of the adopted and non adopted respondents were 4.78 and 5.15 respectively. This signifies that households who adopted the SHS had less family size than nonadopter households. The p-value for family size also indicates that there is a significant $(\mathrm{P}<0.05)$ mean difference between adopter and non-adopter households. 
Regarding the marital status, the majority $(87.3 \%)$ of the respondents were married, while $1.1 \%, 4.6 \%$, and $7 \%$ were single, divorced, and widowed respondents respectively. The chi-square test indicated that there is no statistical association between the marital status of household heads and the decision to adopt SHS.

In the same way, concerning educational level, as shown in table $2,40.7 \%$ of the household heads were illiterate who couldn't read and write. The other $47.71 \%$, $10.24 \%, 0.8 \%, 0.3 \%$, and $0.3 \%$ were basic education (Able to read and write), primary education, secondary education /9-10/, preparatory education /11-12/ and TVET and above the level of education respectively. In the model, this variable is included as literate (households who attended formal education) and illiterate (households who didn't attend formal education). The analysis indicated that more educated households' heads were solar home system adopters compared to nonadopters. The chi-square test showed that there is a statistical association between the education level of household heads and the decision to adopt SHS.

Regarding the type of house, there is a significant difference between adopters and non-adopters. As shown in table 2, 8.1\% of the households had a tin-roofed house with one room, $47.4 \%$ of households had a tin-roofed house with two rooms and the remaining $44.5 \%$ of households had a tin-roofed house with three and above rooms. The analysis indicated that the majority of adopters were owned relatively better housing condition /tin-roofed houses with two rooms and three and above rooms/. But, most of the non-adopter households were inhabited in houses with two rooms and below. The chi-square test indicated that there is a statistical association between the housing type of respondents and SHS adoption.

The majority $(96.5 \%)$ of the households had the opportunity of getting credit. The remaining $3.5 \%$ of respondents had no access to credit. Most of the respondents $(84.6 \%)$ who had no credit access were non-adopters, while $15.4 \%$ were adopters. The Chi-square test for this result shows that there is a statistical association between credit access and SHS adoption.

Out of the total sample, $91.4 \%$ of them reported that they have prior information about the SHS; whereas $8.6 \%$ of respondents confirmed that they have no prior information about the solar home system so far. The chi-square test showed that there 
is a statistical association between prior information/knowledge and the decision to adopt SHS. This result matches with Legesse [19], who proposed that the majority $(84.3 \%)$ of respondents have information about the benefits of renewable energy sources such as solar and biogas while $15.7 \%$ of them have no information in the Ambo district.

About $55.26 \%$ of the respondents received informal /awareness creation/ training on how to utilize SHS products in their homes. The remaining $47.74 \%$ of respondents replayed that they had never received neither formal nor informal training regarding the solar home system. The training was delivered by the energy office of the woreda and solar energy product distributors /agents/ jointly. The chi-square test indicated that there is a statistical association between training and SHS adoption.

As shown in table 2, 51.2\% of the respondents had their mobile cell phones, whereas 48.8\% had no mobile cell phone. More households (65.4\%) who adopted the solar home system had mobile cell phones compared to non-adopters (28.7\%). This indicated that those households who had mobile cell phones had more chances of getting information about the SHS than those who had no mobile cell phones. Similarly, regarding media access, $81.9 \%$ of the total respondents had access to media (79.7\% radio \& $2.2 \% \mathrm{TV}$ ). The remaining $18.1 \%$ had neither radio nor TV. Most of the SHS adopters $(95.2 \%)$ had media access $(91.2 \%$ radio \& $3.9 \% \mathrm{TV})$ compared to non adopters $(60.8 \%)$ (55.9\% radio \& $4.9 \% \mathrm{TV})$. The chi-square test indicated that there is a statistical association between cell phones and SHS adoption as well as media access and SHS adoption.

Regarding electricity, $96.2 \%$ of total household respondents were not accessed. However, only $3.8 \%$ were accessed to electricity. Of those households who had been connected to the grid, $28.57 \%$ was solar energy adopters, whereas $71.43 \%$ were nonadopter households. The chi-square test reveals that there is a statistical relation between grid connection and SHS adoption. 
Table 2: Descriptive statistics of adopters and non-adopters on categorical /discret variables/

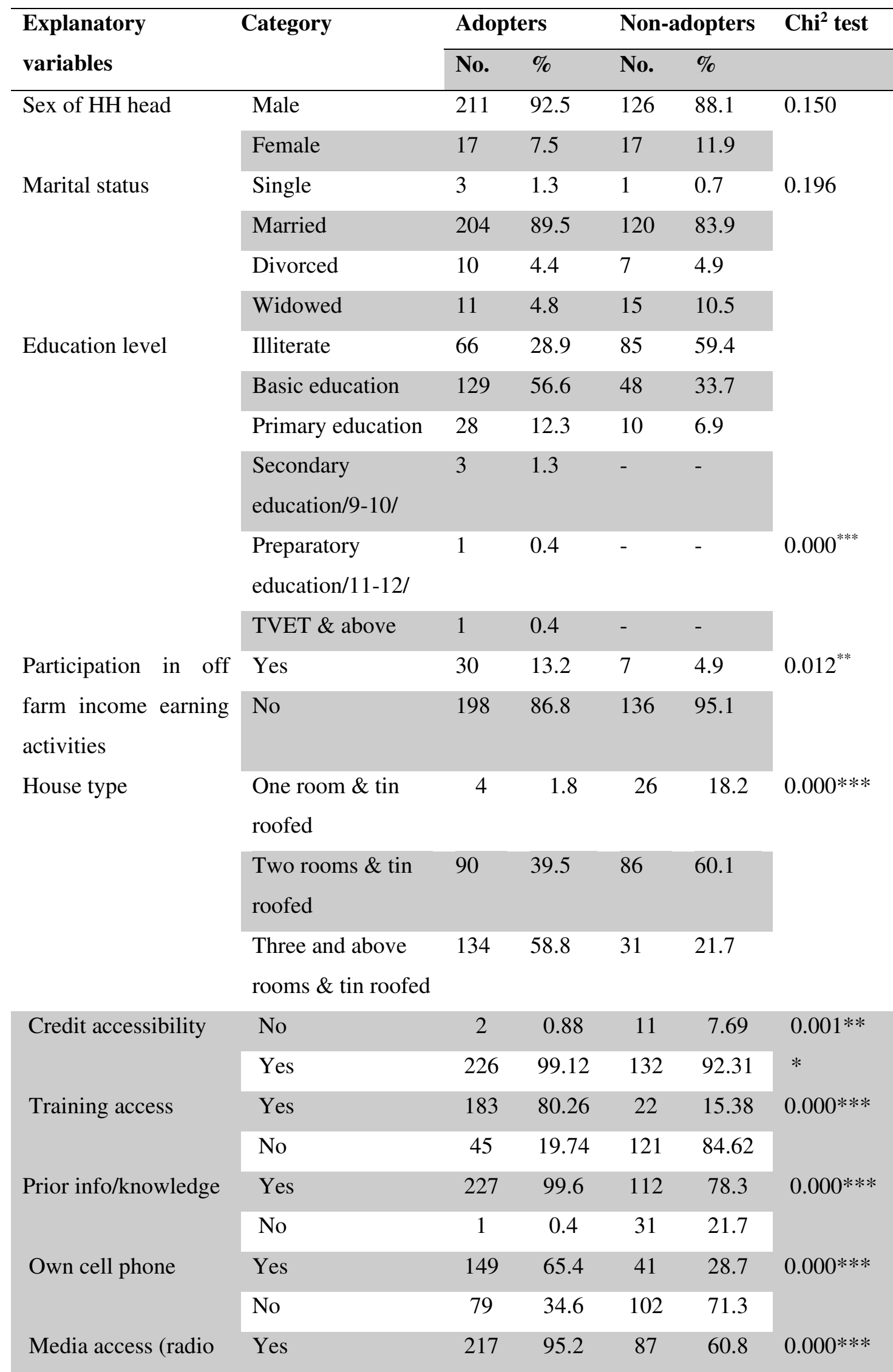




\begin{tabular}{c|ccccc|c} 
or TV, or both) & No & 11 & 4.8 & 56 & 39.2 & \\
Electricity access & Yes & 4 & 1.75 & 10 & 6.99 & $0.010^{* * *}$ \\
& No & 224 & 98.25 & 133 & 93.01 & \\
\hline
\end{tabular}

$* * *, * *$ and $*$ indicate level of significance at $1 \%, 5 \%$ and $10 \%$ respectively.

Regarding landholding, adopter households have more average land size (1.579 hectares) than non-adopters (1.343 hectares). This difference shows a statistically significant at $1 \%$. As shown in table 3 , there is a significant difference between the number of cattle of adopters and non-adopters, where adopters had a higher mean (3.872) than non-adopters (2.678) (tropical livestock unit). TLU is calculated based on the live weight of a mature cow or beef type with the conversion factor of $0.7 \mathrm{LU}$ for herd of cattle [50].

The analysis showed that the mean annual income of SHS adopters (88992.69 Birr) was greater than the mean annual income of non-adopters (66107.45 Birr). The pvalue for income indicates that there is a significant $(\mathrm{P}<0.01)$ mean difference between adopters and non-adopters of the solar home system. Besides, $10 \%$ of the households had additional income sources /off-farm income including remittance $5.4 \%$, handcraft $1.6 \%$, and trade $3 \% /$ in addition to their main income source /agriculture/. But, the majority (90\%) of the households had no additional income. The p-value of the t-test for additional income also shows a significant variation at $5 \%$ between the two groups.

As indicated in table 3, the mean distance of SHS adopted households to the main road was $2.69 \mathrm{~km}$, while the mean distance of respondents who didn't adopt was 3.42 $\mathrm{Km}$. The p-value for the distance of households' home from the main road indicated that there was a significant mean difference $(\mathrm{P}<0.01)$ between the mean of the two groups. Regarding the distance of households' homes from the agricultural extension centre, the mean of adopters (2.79) was relatively less than the mean of non-adopters (3.36). It indicated that most of the non-adopters live relatively far from the agricultural extension centre than adopters. The p-value for this also shows a significant mean variation $(\mathrm{P}<0.01)$ between the two groups. The analysis also shows that the mean distance of adopters $(5.02 \mathrm{~km})$ and non-adopters $(5.88 \mathrm{~km})$ from the market area showed that most of the non-adopters were relatively far from the market area (town) where they couldn't get information and chances of observing SHS 
products. The $\mathrm{p}$-value of the t-test for this also shows a significant mean difference $(\mathrm{P}<0.01)$ between the two groups.

Table 3: Descriptive statistics and test of mean differences of adopters and nonadopters on continuous variables

\begin{tabular}{|c|c|c|c|c|c|}
\hline \multirow[t]{2}{*}{ Explanatory variables } & \multicolumn{2}{|c|}{ Adopters } & \multicolumn{2}{|c|}{ Non-adopters } & \multirow{2}{*}{$\begin{array}{l}\text { P-value } \\
\text { for t-test }\end{array}$} \\
\hline & Mean & Std. Dev. & Mean & Std. Dev. & \\
\hline Age of $\mathrm{HH}$ head & 48.06 & 10.201 & 52.29 & 10.947 & $0.000^{* * * *}$ \\
\hline Family size & 4.78 & 1.519 & 5.15 & 1.477 & $0.020^{* *}$ \\
\hline Land holding size & 1.579 & 0.790 & 1.343 & 0.632 & $0.002^{* * *}$ \\
\hline Household's income & 88992.69 & 37476.82 & 66107.45 & 34806.10 & $0.000^{* * *}$ \\
\hline cattle (TLU) & 3.872 & 2.133 & 2.678 & 1.475 & $0.000^{* * *}$ \\
\hline Dist.road & 2.69 & 2.20 & 3.42 & 2.19 & $0.002 * * *$ \\
\hline Distagri.ext in $\mathrm{km}$ & 2.79 & 1.46 & 3.36 & 1.79 & $0.001 * * *$ \\
\hline Dist market & 5.02 & 1.69 & 5.88 & 1.74 & $0.000 * * *$ \\
\hline
\end{tabular}

$* * *, * *$ and $*$ indicates level of significance at $1 \%, 5 \%$ and $10 \%$ respectively.

\subsection{Econometric results of determinants of solar home system adoption}

Table 4 below summarizes the results of logistic regression on the determinants of household adoption of SHS. The response variable was either adopting or not adopting the SHS. Those households who had SHS were considered as "adopters" and those who had not considered as being "non-adopter".

Before running the regression analysis, the pairwise correlation was conducted to check the existence of multicollinearity among categorical/dummy variables. The result showed that there is no multicollinearity except between marital status and gender, which is 0.828. According to Maddala [51], the correlation value of 0.75 and above indicates a stronger relationship between dummy independent variables. Therefore marital status is excluded from the model to reduce its effect on the regression estimate. The variance inflation factor (VIF) was also computed to test multicollinearity among continuous variables. Thus, since the VIF values are below the cutoff point (5), there is no multicollinearity across continuous independent variables (see appendix A). 
The Hosmer and Lemeshow test is applied to estimate the overall model fit. Since the $\mathrm{p}$-value is greater than statistically significant $(\mathrm{p}<0.05)$, the estimated model has an adequate fit. For this study, the correct model predictions for adopters and nonadopters were $90.8 \%$ and $85.3 \%$ respectively, and the overall correct model prediction was up to $88.7 \%$ on a test set.

Table 4 shows from the total of 18 explanatory variables included in the model, 9 of them were found to have a statistically significant effect on households' decision to adopt SHS. These variables include; income, participation in off-farm income, educational status of households' head, housing type, prior information/knowledge about SHS, gender, training access, media access, and electricity access/connection to the grid. Kebele dummies were also included in the model to control for spatial heterogeneities.

\subsubsection{Income level of household}

The income of the household is found to be one of the important factors in households' decision to adopt a solar home system. The study showed that the income of households has a positive and statistically significant $(\mathrm{P}<0.1)$ effect on solar home system adoption (see Table 4). The odd ratio of the binary logistic regression model indicated that as the income of a household increase by one Birr, the probability of adopting a solar home system increase by a factor of 3.018. This implies that as households become economically strong their propensity to invest in renewable energy technology also increases. This result is consistent with Guta [17], who revealed that as the income of the household become higher, their purchasing power increase and as the same time their demand for solar home system becomes higher. It also agrees with [41], who argued that the income of households is important and has a significant effect on solar home system installation.

Generally, the observed positive correlation in the model estimation indicates the fact that as households got richer, their inclination to pay for clean energy technologies such as solar also increase [17, 41].

\subsubsection{Participation in off-farm income earning activities}

Participation in off-farm income-earning activities is among the main socio-economic factors that influence households' decision to adopt SHS. As shown in table 4, the 
result of logistic regression indicates that off-farm income has a positive effect on solar home system adoption with a statistically significant level $(\mathrm{P}<0.1)$. The odd ratio showed that households who participate in off-farm income-earning activities are more likely to adopt solar by a factor of $4.182(\mathrm{P}<0.1)$ as compared to those households who have no off-farm incomes. This result related to the fact that households who participate in additional off-farm income-earning activities are more economically powerful to invest in SHS for domestic purposes compared to their counterparts [17].

\subsubsection{Housing type of households}

Housing types of households were divided into three categories, namely tin-roofed house with one room, a tin-roofed house with two rooms, and a tin-roofed house with three and above rooms. Households who have a type of house having two rooms and those who have a house with three and above rooms are positively correlated with SHS adoption at a statistically significant level $(\mathrm{P}<0.01)$. The odd ratio of logistic regression indicated that SHS adoption of households having a house with two rooms and house with three and above rooms are higher by a factor of $9.799(\mathrm{P}<0.01)$ and $16.899(\mathrm{P}<0.01)$ respectively as compared to households having a house with one room. The result implies that households who have houses with more rooms tend to use light energy sources (such as solar) that could be available for all rooms at the same time. On the other hand as the size of the home increase, its comfortableness increase to install solar panels up on the roof. This result is consistent with Groote et al [41], who pointed out that houses having larger sizes typically have a larger roof surface that gives more comfort and flexibility to avoid disturbances on the roof and thus resulting in an increased probability of households' adoption of a SHS. Similarly, another study revealed that compared to other energy sources (dry cell and kerosene), solar energy adoption increase as rooms of house increase [6].

\subsubsection{Gender of the households head}

The gender of the head plays a significant role in determining households' decisions to adopt SHS. The result of this study indicated that male household heads are less likely to adopt the SHS by a factor of $6.172(\mathrm{P}<0.05)$ compared to female-headed counterparts. This result supports Guta [17], who found that women are more responsible for the fulfilment of household energy sources in rural Ethiopia. The 
result also corroborates with a previous study by Patrick [40], who argued that women are more active in the participation of environmentally friendly technologies than men, but contrasts with the finding of Anteneh [18], who revealed that male household heads were more likely to adopt solar home system than female counterparts.

\subsubsection{Educational status of households head}

The education status of household heads is one of the key factors determining households' willingness to adopt SHS. According to the model estimation, education status was found to have a positive influence on SHS adoption at statistically significant $(\mathrm{P}<0.05)$. The odd ratio indicated that literate household heads are more likely to adopt SHS by the factor of $21.212(0.05)$ compared to illiterate household heads.

The result reveals the fact that households who have no formal education are less likely to adopt SHS compared to their counterparts. Better exposure to education makes households to be more flexible to know, understand, and aware of new renewable energy technologies and also their health and environmental benefits. This result is consistent with Guta [17], who revealed that education increases households' awareness regarding the health, environmental, economic, and societal relevance of the SHS. This clearly shows that in addition to its role to increase awareness, advancing in education level increases households' earning capacity that endures their capacity to invest in clean energy technologies such as solar. The other study added that as households acquire a better education level, they are more likely to be more informed about the adoption of other best sources of energy [14]. Generally, educated people are fast to improve their awareness level, which leads them to support pro environmental policies for which they are willing and are committed to pay for renewable energy technologies compared to non-educated $[52,14]$.

\subsubsection{Prior information/knowledge}

The result of this study shows that prior knowledge or awareness of households has a positive influence on a household decision to adopt the solar home system at a statistically significant level $(\mathrm{P}<0.05)$. The odd ratio showed that the adoption of respondents who have prior knowledge or information about the SHS is higher by a factor of $547.032(\mathrm{P}<0.05)$ as compared to households who had no prior information 
about solar. This implies that households who have accumulated prior knowledge or awareness are more likely to adopt SHS. However, households who have low awareness or knowledge level, tend to use risky and low efficient energy sources such as kerosene. This is also related to that if they didn't have information about the bad and good side of the new technology, they become reluctant about whether to accept or reject it. This result corresponds with Naomi [32], who found that there is a positive relationship between the adoption of a solar home system and awareness and knowledge about the technology.

\subsubsection{Training access}

Access to training found to have a positive influence on SHS adoption at a statistically significant level $(\mathrm{P}<0.01)$. The odd ratio indicated that the adoption of respondents who have been accessed with training is higher by the factor of 17.949 $(\mathrm{P}<0.01)$ than those who haven't been accessed. This implies that as households got training about the use of the SHS, their propensity to adopt it increase. This means training removes households' previous doubt about the technology and ensures their ability to decide whether to accept or reject it in a reasonable manner. This result confirms the previous study conducted by Keriri [13], revealed that there was a positive relationship between SHS adoption and either formal or informal training delivered. Therefore, the provision of training to rural households increases their awareness level and their inclination to adopt the SHS.

\subsubsection{Media access}

Media accesses found to have a positive influence on SHS adoption at a statistically significant level $(\mathrm{P}<0.01$. The odd ratio indicated that households who accessed with media are more likely to adopt SHS by a factor of $6.242(\mathrm{P}<0.01)$ than those who haven't any media access. This reveals that most of the rural households use radio as a source of new information about new technologies and ideas promptly. The result is consistent with Abera [6], who indicated that access to modern communication technologies such as radio has a positive influence on the adoption of modern and clean energy technologies.

\subsubsection{Electricity access}

Household connection to the grid is also one of the determinants with a negative effect on SHS adoption at a statistically significant level $(\mathrm{P}<0.05)$. The odd ratio of 
SHS adoption showed that the adoption of households who have a grid connection was decreased by a factor of $0.104(\mathrm{P}<0.05)$ compared to households that had no grid connection. This reveals that rural households going to adopt a SHS as an alternative energy source if they haven't electricity access. This result corresponds with previous literature, which stated that in developing countries, the unavailability of grid connection creates an opportunity for solar PV diffusion among potential users more rapidly [16]. 
Table 4: Results of logistic regression model on determinants of households' adoption of solar home system

\begin{tabular}{|c|c|c|c|c|c|}
\hline Variables & Coef. & S.E. & Wald & P-value & $\begin{array}{l}\text { Odds } \\
\text { ratio }\end{array}$ \\
\hline Logincom. & 1.105 & .630 & 3.071 & $.080^{*}$ & 3.018 \\
\hline Off-farmparticip ${ }^{a}$ & 1.431 & .775 & 3.404 & $.065^{*}$ & 4.182 \\
\hline TLU & .066 & .155 & .182 & .669 & 1.068 \\
\hline Land & -.533 & .351 & 2.309 & .129 & .587 \\
\hline Credit $^{b}$ & -1.714 & 1.112 & 2.378 & .123 & .180 \\
\hline House with two rooms ${ }^{c}$ & 2.282 & .880 & 6.730 & $.009 * * *$ & 9.799 \\
\hline $\begin{array}{l}\text { House with three\& above } \\
\text { rooms }^{\mathrm{d}}\end{array}$ & 2.827 & .980 & 8.327 & $.004 * * *$ & 16.899 \\
\hline Gender of head ${ }^{e}$ & -1.820 & .754 & 5.830 & $.016 * *$ & 6.172 \\
\hline Age of head & -.030 & .021 & 2.143 & .143 & .970 \\
\hline Family size & -.184 & .144 & 1.635 & .201 & .832 \\
\hline Education status of head ${ }^{f}$ & 3.055 & 1.302 & 5.505 & $.019 * *$ & 21.212 \\
\hline Prior info ${ }^{g}$ & 6.305 & 2.690 & 5.494 & $.019 * *$ & 547.032 \\
\hline Own cellphone ${ }^{\mathrm{h}}$ & .402 & .433 & .861 & .354 & 1.494 \\
\hline Media access ${ }^{\mathrm{i}}$ & 1.831 & .685 & 7.155 & $.007 * * *$ & 6.242 \\
\hline Training access ${ }^{\mathrm{j}}$ & 2.888 & .409 & 49.899 & $.000 * * *$ & 17.949 \\
\hline Distance to road & -.042 & .117 & .129 & .719 & .959 \\
\hline Distance to farm extension & .061 & .146 & .173 & .677 & 1.063 \\
\hline Distance to market & -.068 & .135 & .257 & .612 & .934 \\
\hline Electricity access ${ }^{\mathrm{k}}$ & -2.263 & 1.004 & 5.082 & $.024 * *$ & .104 \\
\hline Kebele dummies ${ }^{1}$ & yes & & & & \\
\hline Constant & -19.867 & 7.159 & 7.702 & $.006^{* * *}$ & .000 \\
\hline Hosmer \& Lemeshow test & 0.870 & & & & \\
\hline Nagelkerke $\mathrm{R}^{2}$ & 0.742 & & & & \\
\hline Model prediction & 88.7 & & & & \\
\hline -2log likelihood & $201.537^{\mathrm{a}}$ & & & & \\
\hline No. of observation & 371 & & & & \\
\hline
\end{tabular}




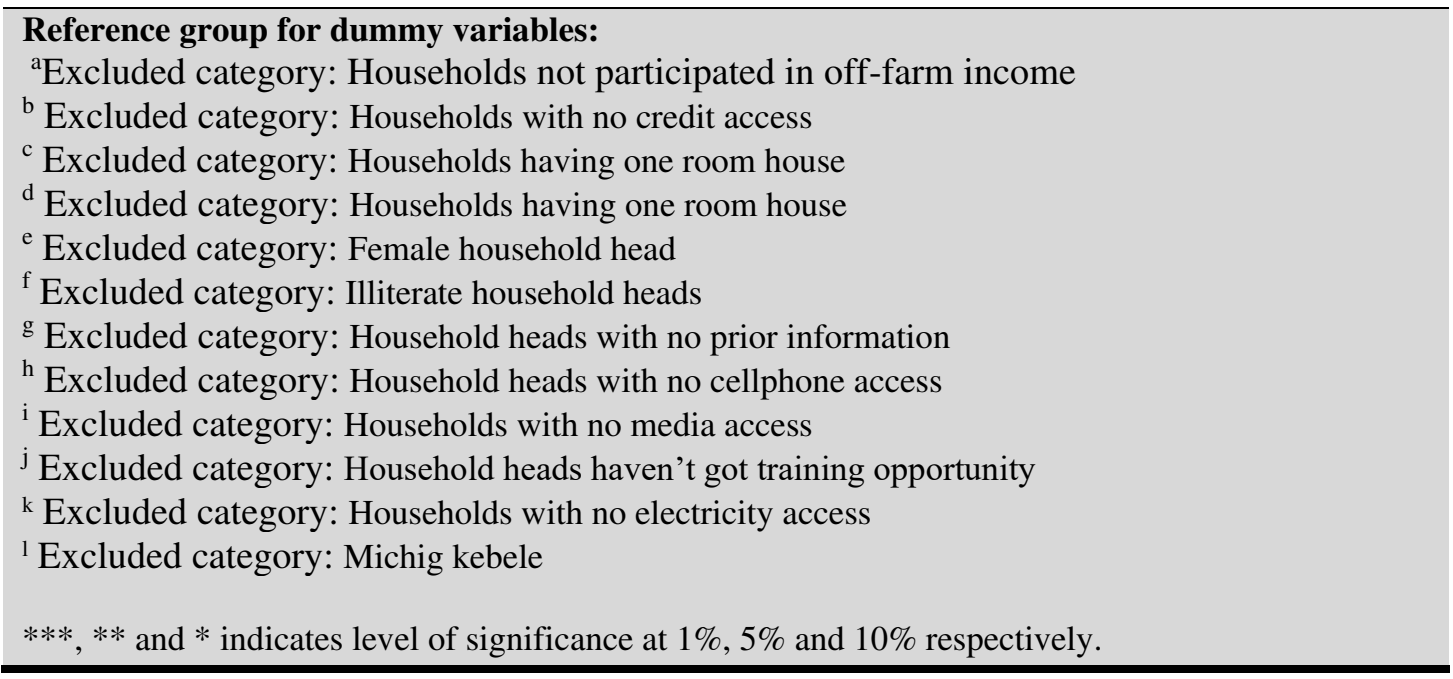

\section{Conclusion}

Using clean and renewable energy sources has paramount importance to reduce adverse health and environmental impacts of using detrimental energy sources especially for citizens from low-income countries like Ethiopia. It is important to understand the underlying factors affecting household adoption of SHS. Previous studies on the factors influencing household SHS adoption overlooked key variables and did not look at the situation in the study area. To fill this gap, the study used data collected from 228 adopters and 143 non-adopters from four kebeles of Baso Liben district, Amhara regional state to investigate factors influencing SHS adoption of rural households. In the study area, only $3.8 \%$ of households had electricity access. Recently, many rural households of the study area have a propensity to adopt SHS. Out of the total sample household respondents, $61.5 \%$ adopted SHS. Based on the finding, adopters and non-adopter households are varied in many demographic and socioeconomic variables.

Binary logistic regression results indicated that variables including income level, offfarm income activity, housing type, household heads' education status, training access, media access, and prior knowledge are statistically significant and have a positive effect on SHS adoption. On the contrary, variables including gender and electricity access are statistically significant but negatively affect SHS adoption. Since economic variables such as income level of household and participation in off-farm income-earning activities are strong predictor variables, appropriate policy options targeted on improving household economic status to reduce poverty is viable to increase their capacity to invest in the SHS. Diversification of income sources of rural 
households through creating different opportunities for off-farm income-generating activities is better to enhance their economic level, which increases their propensity to adopt SHS technology. Improvement of rural households' income level grows not only their willingness to adopt solar but also improves the overall wellbeing of the family. The availability of basic needs including house type could affect the decision to use solar. Mostly, regarding housing type, the number of rooms, and roof quality may influence to install solar. Therefore the improvement of households' economical wellbeing leads them to have better housing type that positively enhances SHS adoption. Efforts targeted on improving educational status have multiple benefits for the rural community. Education boost up households' consciousness level in social, economical, and cultural spheres; helps to generate different income opportunities, and increases awareness that leads them to use clean and modern energy sources rather than using energy sources which are relatively cheap but have detrimental health and environmental effects. Households who got training about the solar home system are more likely to use solar as a source of light for their home. Therefore, rural households should be provided training about the utilization of SHS and its importance properly. Media plays a significant role in accessing accurate and timely information for rural society. It is possible to motivate, aware, or educate most of the rural households at a point in time. Therefore, rural households should be aware to use information sources including radio and other media alternatives as necessary. Moreover, appropriate information should be released using different Media including radio, pamphlets, and brochures for rural households to aware them about the utilization of renewable energy source such as solar as well as their health and environmental values.

This research used cross-sectional data to examine factors influencing SHS adoption. However, investigating the effects of major determinants on solar energy adoption that encompasses a wide range of rural geography and community using longitudinal data is required. Moreover, using an appropriate model, further researches might be conducted on the effects of product-specific attributes including product quality and price on household adoption of the SHS. 


\section{Abbreviations}

CSA: Central statistical Agency

HH: Household

ICF: International Care Facility

MoWIE: Ministry of Water Irrigation and Electricity

PV: Photo Voltaic

REEEP: Renewable Energy and Energy Efficiency Partnership

REN: Renewable Energy Policy Network

SHS: Solar Home System

TERI: The Energy and Resource Institute

UNEP: United Nation Environmnet program

VIF: Variance Inflation Factor

\section{Acknowledgment}

We would like to express our deep gratitude to Baso Liben woreda administrative and energy office experts, kebele experts, and rural household interviewees for their willingness to give us their priceless information. We also thanks the editor, Mihretu Yihunie Yalew, for his very valuable contribution in language editing work for this manuacript.

\section{Ethical approval and consent to participate}

Not applicable.

\section{Consent for publication}

Not applicable

\section{Availability of supporting data}

All relevant data are incorporated into this manuscript. So, there is no other data to be supplemented. 


\section{Competing interest}

The authors declare that they have no competing interests.

\section{Funding}

The paper was not financially supported by anybody.

\section{Authors' contribution}

AM collected the data, estimated the model, and prepared the draft manuscript. DD critically read the manuscript, made suggestions and provided valuable inputs to finalize the manuscript. All authors read and approved the manuscript. 


\section{REFERENCES}

[1] UNEP (2017) Atlas of Africa Energy resource. Available at: https://wedocs.unep.org/bitstream/handle/20.500.11822/20476/Atlas_Africa_E nergy_Resources.pdf.

[2] Hannah Ritcher (2019) renewable energy. Published online at OurWorldInData.org. Retrieved from. https://ourworldindata.org/renewableenergy

[3] IEA (2020) Global Energy Review 2020. Available at: https://www.iea.org/reports/global-energy-review-2020/renewables

[4] Brüderle, A., Attigah, B., and M. Bodenbender (2011) Productive Use of Energy produce: A Manual for Electrification Practitioners. GIZ and EUEI PDF, Eschborn, http://www.produse.org/manual

[5] MoWIE (2019) National Electrification Program 2.0. ntegrated Planning for Universal Access. Ministry of Water, Irrigation and Electricity.Available at: https://www.africa-energy-forum.com/article/ethiopia-national-electrificationprogram-20-report.

[6] Abera, Y., Fenta, K (2019) Determinants of Lighting Energy Transitions in Rural Ethiopia: Lessons from Mida Oromo and Wonisho Districts of Ethiopia. Environmental Management and Sustainable Development, doi:10.5296 e msd v 8 i 315151

[7] NASA (2013) Surface Metrology and solar energy, available from http://eosweb. Iarc.nasa.gov/cgi-bin/sse/sse.cgi?

[8] Deribew, D (2013) Ethiopia's Renewable Energy Power Potential and Development Opportunities. Ministry of Water and Energy. Avaiable at: https://www.ctc-n.org/sites/www.ctc-n.org/files/resources. Accessed 20 Dec 2020.

[9] Guta, D and Borner, J (2017) Energy security, uncertainty and energy resource use options in Ethiopia. A sector modeling approach. International Journal of Energy Sector Management, 11(1): 91-117

[10] Lighting Africa (2012) Policy Report- Ethiopia. Available at: https://www.lightingafrica.org/publication/lighting-africa-policy-report-noteethiopia/

[11] TERI (2014) Dissemination of solar Energy Technoogies in Ethiopia: successes, challenges and opportunities. National workshop. Addis Ababa, May 19-20, 2014 
[12] Mekuria, E ( 2016) Challenges and Prospects of Solar Home System Dissemination in Rural Parts of Ethiopia. Thesis, Addis Ababa University.

[13] Keriri, I (2013) Factors Influencing Adoption of Solar home system in Lakipia North constituency, Kenya. Thesia, University of Nairobi. Available at: http://erepository.uonbi.ac.ke/bitstream/handle/11295/56297/keriri_Factors influencing adoptionofSolar home system.pdf?sequence $=5$.

[14] Gitone, I (2014) Determinants of Adoption of Renewable Energy in Kenya. Thesia, University of Nairobi.

[15] Regina, G (2016) Solar home system adoption at Household level. Unite States International University. Thesis, United States International University- Africa

[16] Tahir, M., Kafait, U., Marten J., A (2017) Factors responsible for solar PV adoption at household level: A case of Lahore, Pakistan. Renewable and Sustainable Energy Reviews, 78: 756-762.

[17] Guta, D (2018) Determinants of Household Adoption of solar home system in Rural Ethiopia. Journal of Cleaner Production, doi: 10.1016/j.jclepro.2018.09.016.

[18] Anteneh, C (2019) The Determinants of Households' Adoption of Solar Energy in Rural Ethiopia: The case study of Gurage Zone. Thesis, Addis Ababa University.

[19] Legesse, W (2016) Determinants of Adoption of Renewable Energy Sources towards Reducing Deforestation in Ambo district, West Shoa, Oromia Regional State, Ethiopia. Journal of Energy Technologies and Policy 6(11): 27-33.

[20] Ajzen, D. E (1985) Intention, perceived control, and weight loss: An application of the theory of plannedbehavior, University of Massachusetts at Amherst. Journal of Personality and Social Psychology 49 (3), 844-849.

[21] Fishbein, M., \& Ajzen, I (1975) Belief, Attitude, Intention, and Behavior: An Introduction to Theory and Research. Reading, MA: Addison-Wesley.

[22] Rogers, E.M (2003) Diffusion of Innovation, 5th edition. New York: Free Press.

[23] Hosier, R (1987) Household fuel choice in Zimbabwe: An empirical test of the energy ladder hypothesis. Resources and Energy, 9 (4), 347-361. 
[24] Heltberg, R (2003) Household Fuel and Energy use in Developing countries- A multicountry study. Oil and Gas Policy Division, The world Bank. Available at https://www.esmap.org, 22-45.

[25] Ekholm, Tommi, Volker Krey, Shonali Pachauri, and Keywan Riahi 2010 "Determinants of Household Energy. Consumption in India." Energy Policy 38 (10): 5696-5707.

[26] Dil Bahadur Rahut, Khondoker Abdul Mottaleb, Akhter Ali \& Jeetendra Aryal (2018) The use and determinants of solar energy by Sub-Saharan African households, International Journal of Sustainable Energy, 37:8, 718-735. DOI: $10.1080 / 14786451.2017 .1323897$

[27] Solangi, K. H., M. R. Islam, R. Saidur, N. A. Rahim, and H. Fayaz ( 2011) “A Review on Global Solar Energy Policy. ”Renewable and Sustainable Energy Reviews 15 (4): 2149-2163.

[28] Renewable Energy Policy Network for 21 Century - REN21. Global status report. Available at: http://www.ren21.net/wp-content/uploads/2016/06/ GSR_2016_FullReport_.pdf.

[29] Eronini, Nnamdi (2014) The Adoption of Solar Photovoltaic Systems among Industries and Residential Houses in Southern Nigeria. Östersund, Mid Sweden University.

[30] GOGLA (2018) Off-grid solarmarket trends report 2018.Washington DC.

Retrieved from https://www.lightingglobal.org/wpcontent/uploads/2018/02/2018_Off_Grid_Solar_Market_Trends_Report_Sum mary.pdf

[31] Kizilcec, V and Parikh (2020) Solar Home Systems: A comprehensive literature review for Sub-Saharan Africa. Energy for Sustainable Development 58 (2020) $78-89$

[32] Naomi, N (2014) Factors affecting the adoption of solar power for domestic usage in Kajiado country kenya. Thesis, University of Nairobi.

[33] Bandara, U.C.; Amarasena, T.S.M (2020) Impact of Perceived Ease of Use, Awareness and Perceived Cost on Intention to Use Solar Energy Technology in Sri Lanka. Journal of International Business and Management. Available at: https://doi.org/10.37227/jibm-2020-04-61

[34] Rashid, S. S (2012) Intention to Use Renewable Energy: Mediating role of Attitude. Energy Research Journal, 3(2): 3-5. 
[35] Beyene, G.E., Kumie, A., Edwards, R. \& Troncoso, K. (2018). Opportunities for transition to clean household energy in Ethiopia: application of the household energy assessment rapid tool (HEART). World Health Organization. https://apps.who.int/iris/handle/10665/311280.

[36] Corfee-Morlot, Jan; Parks, Paul; Ogunleys, James \& Ayeni, Famous (2019) Achieving Clean Energy Access in Sub-Saharan Africa- A case study prepared for the OECD project "Financing Climate Future"

[37] Mishra, K. (2018) "You are Approved! Insured Loans Improve Credit Access and Technology Adoption of Ghanaian Farmers," 2018 Conference, July 28August 2, 2018, Vancouver, British Columbia 277089, International Association of Agricultural Economists.

[38] Mbachu, C.I. and Bizien, Q. (2017). Adoption of innovation: A qualitative research about employees' adoption of information technological tool (ERP) within an organization. Department of Business Administration, Linnaeus University, Växjö - Sweden.

[39] Ali, A. H (1997) Training and professional development in improving agricultural extension. A reference manual. Food and Agricultural Organization of the United Nations, P. 190-200.

[40] Patrick, W (2007) Reconsidering Public Attitudes and Public Acceptance of Renewable Energy Technologies: A Critical Review. Available via: http://www.sed.manchester.ac.uk/research/beyond_nimbyism/.

[41] De Groote, O., Pepermans, G., Verboven, F. (2016) Heterogeneity in the Adoption of Photovoltaic Systems in Flanders, Energy Economics, doi: 10.1016/j.eneco.2016.07.008

[42] George, D., \& Mallery, P (2003) SPSS for Windows step by step: A simple guide and reference. 11.0 update (4th ed.). Boston, Allyn \& Bacon.

[43] Gujarati (2004) Basic Econometrics, Topics in Econometrics 15.Qualitative Response Regression Models. The McGraw-Hill Companies. Fourth Edition

[44] Pindyck R S, Rubinfeld D L (1981) Econometric Models and Economic Forecasts. McGraw-Hill, New York.

[45] Akinwale, Y.O. and Adepoju, O. A (2019) Factors influencing willingness to adopt renewable energy technologies among micro and small enterprises in 
Lagos State Nigeria. International Journal os Sustainable Energy planning and management 19: 69-78.

[46] Park, H.-A (2013) An Introduction to Logistic Regression: From Basic Concepts to Interpretation with Particular Attention to Nursing Domain. Journal of Korean Academic of Nurrsing. Available at: http://dx.doi.org/10.4040/jkan.2013.43.2.154, 13(2):154-162.

[47] Carson, D (2008) 'The "Blogosphere" as a Market Research Tool for Tourism Destinations: A Case Study of Australia's Northern Territory', Journal of Vacation Marketing 14(2): 99-107.

[48] Obayelu A, Ajayi O, Oluwalana E, Ogunmola O ( 2017) What Does Literature Say About the Determinants of Adoption of Agricultural Technologies by Smallholders Farmers?. Agri Res \& Tech: Open Access J. 6(1): 555676. DOI: 10.19080/ARTOAJ.2017.06.555676.

[49] CSA and ICF (2016) Ethiopian Demographic and Health Survey. Addis Ababa,Ethiopia, and Rockville, Maryland: CSA and ICF.

[50] FAOSTAT (200) FAOSTAT data. Rome.

[51] Maddala, G.S (1992) Introduction to Econometrics. Second Edition. Macmillan Publishing Company, New York.

[52] Guta, D (2020) determinants of household use of energy-efficient and renewable energy technologies in rural ethiopia. Technology in society. https://doi.org/10.1016/j.techsoc.2020.101249 


\section{APPENDIX A}

\section{Multicollinearity test of dummy independent variables using pair wise}

\section{correlation}

Correlations

\begin{tabular}{|c|c|c|c|c|c|c|c|c|c|c|c|c|}
\hline & & Gender & $\begin{array}{l}\text { marital } \\
\text { status }\end{array}$ & $\begin{array}{c}\text { Educa } \\
\text { tion } \\
\text { status }\end{array}$ & $\begin{array}{l}\text { off farm } \\
\text { particip } \\
\text { ation }\end{array}$ & Credit & $\begin{array}{l}\text { Hous } \\
\text { e type }\end{array}$ & $\begin{array}{c}\text { mobile } \\
\text { phone } \\
\text { access }\end{array}$ & $\begin{array}{l}\text { media } \\
\text { access }\end{array}$ & $\begin{array}{l}\text { Training } \\
\text { access }\end{array}$ & $\begin{array}{l}\text { Electricit } \\
\text { y access }\end{array}$ & $\begin{array}{l}\text { Prior } \\
\text { info. }\end{array}$ \\
\hline \multirow[t]{3}{*}{ Gender } & $\begin{array}{l}\text { Pearson } \\
\text { Correlation }\end{array}$ & 1 & $.828^{* *}$ & -.057 & .019 & $-.143^{* *}$ & $.169^{-}$ & $-.232^{\star *}$ & $-.264^{\star *}$ & & -.014 & -.069 \\
\hline & Sig. (2-tailed) & & .000 & .277 & .715 & .006 & .001 & .000 & .000 & .014 & .790 & .186 \\
\hline & $\mathrm{N}$ & 371 & 371 & 371 & 371 & 371 & 371 & 371 & 371 & 371 & 371 & 371 \\
\hline \multirow[t]{3}{*}{$\begin{array}{l}\text { marital } \\
\text { status }\end{array}$} & $\begin{array}{l}\text { Pearson } \\
\text { Correlation }\end{array}$ & & 1 & & & & $.168^{* *}$ & & & & .040 & -.076 \\
\hline & Sig. (2-tailed) & .000 & & .185 & .872 & .001 & .001 & .000 & .000 & .009 & .448 & .143 \\
\hline & $\mathrm{N}$ & 371 & 371 & 371 & 371 & 371 & 371 & 371 & 371 & 371 & 371 & 371 \\
\hline \multirow{3}{*}{$\begin{array}{l}\text { Educati } \\
\text { on } \\
\text { status }\end{array}$} & $\begin{array}{l}\text { Pearson } \\
\text { Correlation }\end{array}$ & -.057 & -.069 & 1 & -.036 & .069 & .099 & $.118^{\star}$ & $.148^{\star *}$ & $.190^{\star *}$ & -.072 & .081 \\
\hline & Sig. (2-tailed) & .277 & .185 & & .487 & .185 & .057 & .024 & .004 & .000 & .168 & .118 \\
\hline & $\mathrm{N}$ & 371 & 371 & 371 & 371 & 371 & 371 & 371 & 371 & 371 & 371 & 371 \\
\hline \multirow{3}{*}{$\begin{array}{l}\text { off farm } \\
\text { particip } \\
\text { ation }\end{array}$} & $\begin{array}{l}\text { Pearson } \\
\text { Correlation }\end{array}$ & & & -.036 & 1 & .063 & $.108^{\star}$ & & & .101 & .076 & .038 \\
\hline & Sig. (2-tailed) & .715 & .872 & .487 & & .223 & .037 & .716 & .098 & .053 & .146 & .464 \\
\hline & $\mathrm{N}$ & 371 & 371 & 371 & 371 & 371 & 371 & 371 & 371 & 371 & 371 & 371 \\
\hline \multirow[t]{3}{*}{ Credit } & $\begin{array}{l}\text { Pearson } \\
\text { Correlation }\end{array}$ & & & & & 1 & $.157^{* *}$ & $.195^{\star *}$ & & & -.039 & $.150^{\star \star}$ \\
\hline & Sig. (2-tailed) & .006 & .001 & .185 & .223 & & .002 & .000 & .000 & .000 & .452 & .004 \\
\hline & $\mathrm{N}$ & 371 & 371 & 371 & 371 & 371 & 371 & 371 & 371 & 371 & 371 & 371 \\
\hline \multirow[t]{3}{*}{$\begin{array}{l}\text { House } \\
\text { type }\end{array}$} & $\begin{array}{l}\text { Pearson } \\
\text { Correlation }\end{array}$ & $-.169^{* \star}$ & $-.168^{\star *}$ & .099 & $.108^{*}$ & $.157^{\star \star}$ & 1 & $.386^{\star *}$ & $.395^{\star *}$ & $.323^{\star *}$ & .088 & $.194^{* \star}$ \\
\hline & Sig. (2-tailed) & .001 & .001 & .057 & .037 & .002 & & .000 & .000 & .000 & .090 & .000 \\
\hline & $\mathrm{N}$ & 371 & 371 & 371 & 371 & 371 & 371 & 371 & 371 & 371 & 371 & 371 \\
\hline \multirow{3}{*}{$\begin{array}{l}\text { mobile } \\
\text { phone } \\
\text { access }\end{array}$} & $\begin{array}{l}\text { Pearson } \\
\text { Correlation }\end{array}$ & $-.232^{* \star}$ & $-.237^{\star *}$ & & & & $.386^{* *}$ & 1 & $.439^{* *}$ & & .023 & \\
\hline & Sig. (2-tailed) & .000 & .000 & .024 & .716 & .000 & .000 & & .000 & .000 & .652 & .006 \\
\hline & $\mathrm{N}$ & 371 & 371 & 371 & 371 & 371 & 371 & 371 & 371 & 371 & 371 & 371 \\
\hline \multirow[t]{3}{*}{$\begin{array}{l}\text { media } \\
\text { access }\end{array}$} & $\begin{array}{l}\text { Pearson } \\
\text { Correlation }\end{array}$ & $-.264^{* \star}$ & $-.257^{* *}$ & $.148^{* *}$ & .086 & $.330^{* *}$ & $.395^{* *}$ & $.439^{\star \star}$ & 1 & $.339^{\star *}$ & .056 & $.180^{\star \star}$ \\
\hline & Sig. (2-tailed) & .000 & .000 & .004 & .098 & .000 & .000 & .000 & & .000 & .280 & .000 \\
\hline & $\mathrm{N}$ & 371 & 371 & 371 & 371 & 371 & 371 & 371 & 371 & 371 & 371 & 371 \\
\hline \multirow[t]{3}{*}{$\begin{array}{l}\text { Training } \\
\text { access }\end{array}$} & $\begin{array}{l}\text { Pearson } \\
\text { Correlation }\end{array}$ & $-.128^{*}$ & $-.136^{\star *}$ & $.190^{\star *}$ & .101 & $.212^{* \star}$ & $.323^{\star *}$ & $.358^{\star *}$ & $.339^{* *}$ & 1 & $-.135^{\star *}$ & $.226^{\star *}$ \\
\hline & Sig. (2-tailed) & .014 & .009 & .000 & .053 & .000 & .000 & .000 & .000 & & .009 & .000 \\
\hline & $\mathrm{N}$ & 371 & 371 & 371 & 371 & 371 & 371 & 371 & 371 & 371 & 371 & 371 \\
\hline \multirow{3}{*}{$\begin{array}{l}\text { Electrici } \\
\text { ty } \\
\text { access }\end{array}$} & $\begin{array}{l}\text { Pearson } \\
\text { Correlation }\end{array}$ & -.014 & .040 & -.072 & .076 & -.039 & .088 & .023 & .056 & $-.135^{\star *}$ & 1 & .010 \\
\hline & Sig. (2-tailed) & .790 & .448 & .168 & .146 & .452 & .090 & .652 & .280 & .009 & & .841 \\
\hline & $\mathrm{N}$ & 371 & 371 & 371 & 371 & 371 & 371 & 371 & 371 & 371 & 371 & 371 \\
\hline \multirow[t]{3}{*}{$\begin{array}{l}\text { prior } \\
\text { info }\end{array}$} & $\begin{array}{l}\text { Pearson } \\
\text { Correlation }\end{array}$ & -.069 & -.076 & .081 & .038 & $.150^{* *}$ & $.194^{* *}$ & $.142^{\star *}$ & $.180^{\star *}$ & $.226^{\star \star}$ & .010 & 1 \\
\hline & Sig. (2-tailed) & .186 & .143 & .118 & .464 & .004 & .000 & .006 & .000 & .000 & .841 & \\
\hline & $\mathrm{N}$ & 371 & 371 & 371 & 371 & 371 & 371 & 371 & 371 & 371 & 371 & 371 \\
\hline
\end{tabular}

**. Correlation is significant at the 0.01 level (2-tailed)

*. Correlation is significant at the 0.05 level (2-tailed). 
Multicollinearity test of continuous independent variables using VIF

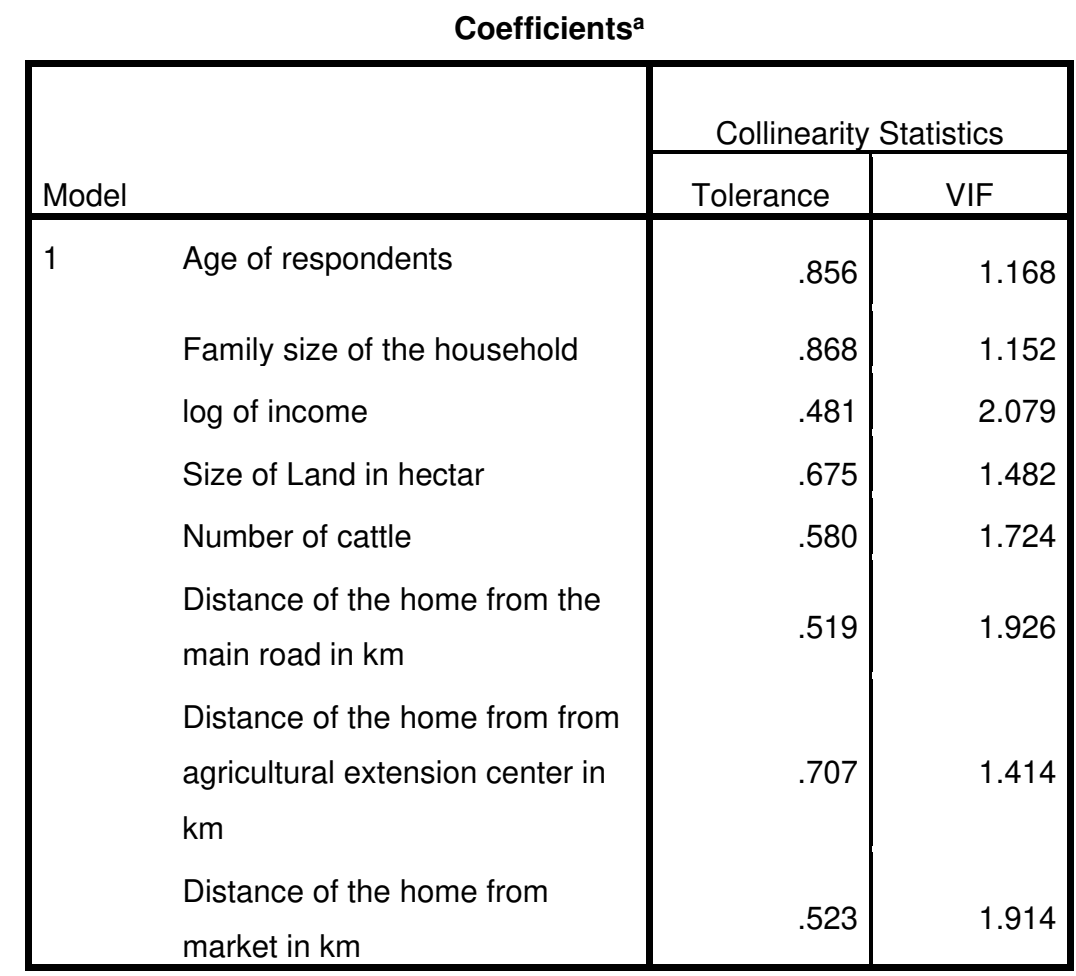

a. Dependent Variable: Solar installation in the household 
Figures

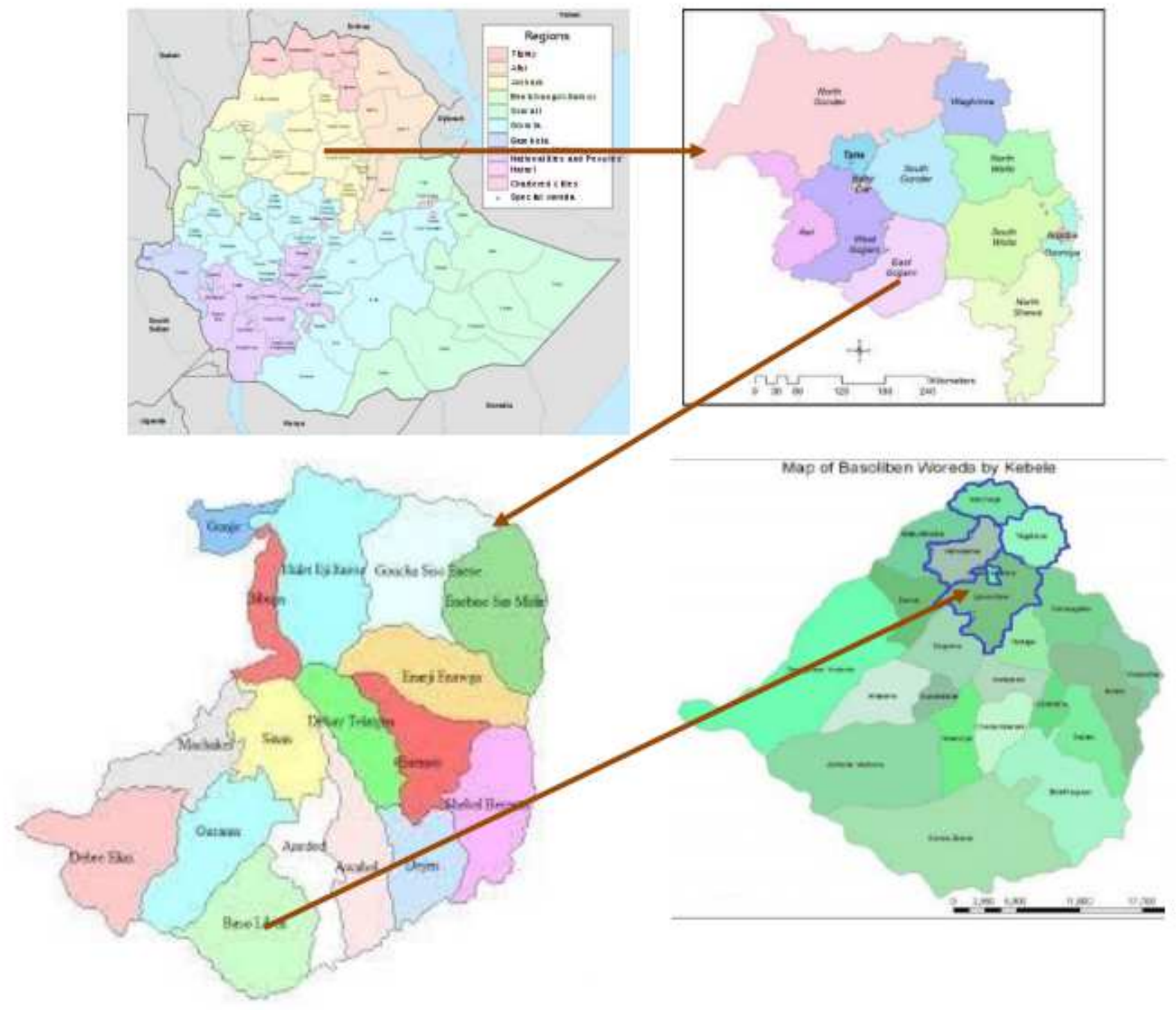

Figure 1

Map of the study area 